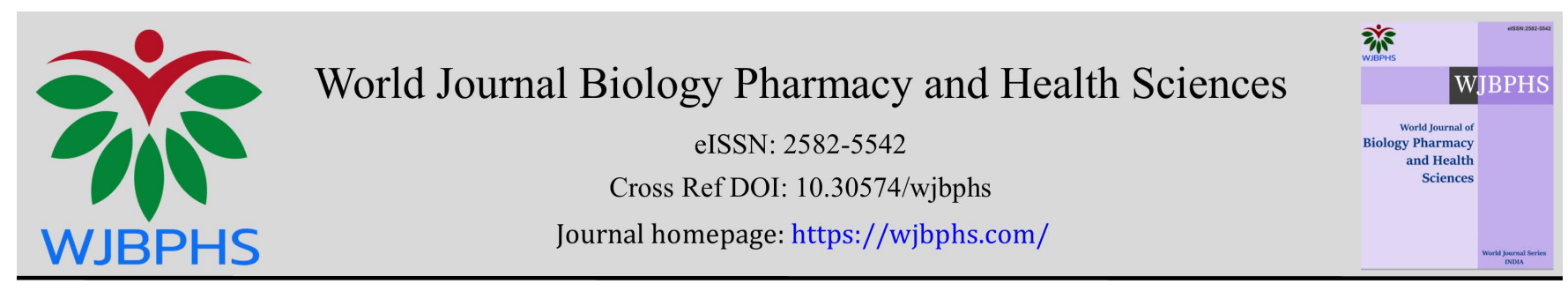

(RESEARCH ARTicle)

Check for updates

\title{
Leucocytes, urea and glucose levels in Albino Wistar rats exposed to doses of isolated Achatina achatina snail lectin
}

\author{
Odiegwu C.N.C. ${ }^{1,}{ }^{*}$, Chianella I. ${ }^{2}$, Odiegwu U.O. ${ }^{3}$, Okolie U.V. ${ }^{4}$, Ifejirika E.C. 5 \\ ${ }^{1}$ Department of Medical Laboratory Science, College of Health Sciences, Nnamdi Azikiwe University-Nnewi Campus, \\ Anambra State, Nigeria. \\ ${ }^{2}$ School of Aerospace, Transport \& Manufacturing, Building 70 F07, Cranfield University, Cranfield, Bedfordshire, England, \\ United Kingdom. \\ ${ }^{3}$ Department of Statistics, Faculty of Physical Sciences, Nnamdi Azikiwe University, Awka, Anambra State, Nigeria. \\ ${ }^{4}$ Department of Nutrition \& Dietetics, Michael Okpara University of Agriculture, Umudike, Abia State, Nigeria. \\ ${ }^{5}$ Department of Pharmacognosy \& Traditional Medicine, Faculty of Pharmaceutical Sciences, Chukwuemeka Odumegwu \\ Ojukwu University, Igbariam, Anambra State, Nigeria.
}

World Journal of Biology Pharmacy and Health Sciences, 2021, 06(03), 001-012

Publication history: Received on 12 April 2021; revised on 21 May 2021; accepted on 24 May 2021

Article DOI: https://doi.org/10.30574/wjbphs.2021.6.3.0052

\begin{abstract}
There are five (5) types of mature White blood cells (WBC) or Leucocytes found in the peripheral blood viz, Neutrophils (NEU), Eosinophils (EOS) and Basophils (BAS) (granulocytes); Monocytes (MON) and Lymphocytes (LYM) (agranulocytes). Urea is an organic chemical compound, and is essentially the waste produced by the body after metabolizing protein. Urea levels can be used to detect diseases and disorders that affect the kidneys. A common disease related to irregular management of glucose is diabetes. Lectins are proteins that recognize specifically and bind reversibly the carbohydrate-containing molecules of foreign cells and that elicit diverse physiological responses in various organisms. A total of 120 samples of Nigeria Achatina achatina snail specie were collected, authenticated at the Zoology Department of University of Nigeria, Nsukka and $80 \mathrm{mls}$ of pooled crude Lectin extract was obtained. Purifications were performed on $20 \mathrm{mls}$ of the crude extract in three steps viz, Ammonium sulphate precipitation and Dialysis (Partial purifications), Con A Sepharose 4B affinity Chromatography column (Complete purification). The affinity purified Lectin was used for all the tests conducted in this research. The crude, partially and complete/affinity purified Lectin extracts were subjected to Haemagglutination tests. The Lectin was further assessed to determine its effects on Leucocytes, Urea and Glucose as follows: A total of Thirty-five (35) male Albino Wistar Rats weighing 101$180 \mathrm{~g}$ and aged 2-3 months obtained from the Animal house of University of Nigeria, Nsukka, were used in this research. The animals were Grouped into 5 (A-E) and allowed for 2 weeks acclimatization. Graded doses of $0.04 \mathrm{ml}, 0.05 \mathrm{ml}$ and $0.06 \mathrm{ml}$ of the Affinity purified Lectin were injected intra-peritoneally into each of the Rats in Groups A-D (test groups) according to their body weights at intervals of 2 days for 1 week. Group E served as the control. Two (2) mls of blood was collected from each of the Rats before and 24 hours after the last day of Lectin Doses injections for the following tests: WBC-Total and Differential counts (using Sysmex Corporation, 1999 automated equipment), Urea and Glucose estimations (performed by means of Urease-Berthelot and GOD-PAP Randox Monza automated analyser methods respectively). The results of the research showed as follows: On complete/affinity purification, $15 \mathrm{mls}$ of pure sample containing only the high molecular weight Lectin was obtained. The haemagglutination tests conducted showed on standardization preferential agglutination with Blood group A type. Bar Charts statistics show that there was Post Lectin Doses injections mean increase in Total WBC, NEU, LYM and decrease in MON, EOS, BAS, Urea and Glucose levels. However, the differences in Pre and Post Lectin Doses injections mean values of these parameters were further subjected to One way analysis of variance (ANOVA) test statistics to determine if statistically significant. The ANOVA
\end{abstract}

${ }^{*}$ Corresponding author: Odiegwu CNC

Department of Medical Laboratory Science, College Of Health Sciences, Nnamdi Azikiwe University-Nnewi Campus, Anambra State, Nigeria.

Copyright (c) 2021 Author(s) retain the copyright of this article. This article is published under the terms of the Creative Commons Attribution Liscense 4.0. 
statistics show that the effects of the Lectin on all the assessed Leucocytes parameters viz, Total WBC, and Differential LYM, NEU, MON, EOS, BAS, the Urea and Glucose levels were found to be statistically insignificant. However, the EOS values of only group A was statistically significant. This research has therefore succeeded in Assessment of Activities of the $A$. achatina snail Lectin on Leucocytes, Glucose and Urea levels.

Keywords: Achatina achatina; Snail Lectin; Effects on Leucocytes; Glucose; Urea

\section{Introduction}

Haemopoiesis is the process by which blood cells are formed. Blood is composed of a pale yellow fluid called plasma in which are suspended Red cells (Erythrocytes), White cells (Leucocytes), and Platelets (Thrombocytes). Plasma forms about $55 \%$ of blood volume and contains mineral ions, organic molecules, hormones, enzymes, products of digestion, and waste products for excretion [1]. The process by which White Blood Cells (WBC) are formed is known as Leucopoiesis. Under normal conditions, Five (5) types of mature white blood cells or Leucocytes are found in the peripheral blood. Three of these types contain granules in their cytoplasm, and are therefore called granulocytes. Depending on the nature of the granules, they are called Neutrophils, Eosinophils and Basophils. The other two types of cells, called agranulocytes, are Monocytes and Lymphocytes. Granulocytes and Monocytes are formed in the bone marrow from a pluripotential cell by differentiation, proliferation and maturation. Maturation of lymphocytes takes place in the Reticulo-endothelial system [2].

Karl Landsteiner in 1900 in his Iso-agglutination experiments in which he mixed Red cell from one person with sera from another person led to discovering A, B, O groups [3].

Lectins are a diverse group of proteins that bind specifically various carbohydrates. The binding of Lectins to carbohydrates is non-covalent and reversible, involving hydrogen bonds, hydrophobic, electrostatic and van der Waals interactions and dipole attraction [4]. Hence, Lectins can be defined as proteins or glyco-protein substances, of nonimmunoglobulin nature, capable of specific recognition of and reversible binding to, carbohydrate moieties of complex glyco-conjugates without altering the covalent structure of any of the recognized glycosyl ligands [5]. These Lectins bind to sugar moieties in cell walls or membranes and thereby change the physiology of the membranes to cause agglutination, mitosis or other biochemical changes in the cell. Lectins have properties such as specificity for human blood groups, toxicity in animals and humans, induction of mitosis in lymphocytes, agglutination of malignant cells, precipitation of polysaccharides and glyco-proteins and binding of sugars [6].

There has been some information that Lectins may be inactivated by soaking, sprouting, cooking or fermenting. Soaking legumes overnight, draining the water, rinsing and draining again does seem to remove or inactivate many of the Lectins. Heating seems to remove others in some foods but not all. There is little data to prove that any of these methods remove Lectins completely as few foods have been tested and of those that have Lectins many seem to remain after processing. Lectins from green salads, fruits, spices, seeds, dry cereal and nuts (even after roasting) showed activity of potentially toxic Lectins. Some of these Lectins interact with serum or salivary components and bacteria from the oral cavity. Also, it has been shown that unrefined soy oils contained $858-2983 \mathrm{mcg} / \mathrm{kg}$ and the refined oils contained $24-$ $55 \mathrm{mcg} / \mathrm{kg}$. Hence, both refined and unrefined soy oils contained soy Lectins [7].The safest path is avoidance of known toxic Lectins.

The common features of toxic (non-nutritive) effects in Lectins-gut interactions include:

- High degree of resistance to gut proteolysis.

- Binding to brush border cells; damage to micro villus membrane; shedding of cells; reduction in the absorptive capacity of the small intestine.

- Increased endocytosis; induction of hyper plastic growth of the small intestine; increased turnover of epithelial cells.

- Interference with the immune system; hypersensitivity reactions.

- Interference with the microbial ecology of the gut; selective over growth.

- $\quad$ Direct and indirect effects (hormones, etc.) on systemic metabolism.

One becomes Lectin sensitive because of a failure of SIgA barrier protection, genetic or environmentally induced, bacterial or virus infection, certain bacteria and virus, including the influenza virus, can damage cells making them susceptible to Lectin antibody - antigen reactions or by the use of non-steroidal anti-inflammatory (NSAIDs) or other drugs which increase gut permeability and allow Lectins to enter general circulation. Celiac-sprue is a genetic disorder 
treated by elimination of offending foods. Historical diagnosis and treatment of Celiac-sprue is related to 'gliadin' (also known as gluten) sensitivity. Gliadin is found in wheat, rye, barley, oats and foods containing these grains (including beer, grain based alcohols, mayonnaise, grain vinegar, etc.). If all cases of Lectin intolerance were genetically based, reversal of intolerance would not be possible. Tests are available to determine SIgA levels and gut immune reactions to soy, dairy, wheat and egg [8].

Urea, also called carbamide, is an organic chemical compound, and is essentially the waste produced by the body after metabolizing protein. Naturally, the compound is produced when the liver breaks down protein or amino acids, and ammonia; the kidneys then transfer the urea from the blood to the urine. Extra nitrogen is expelled from the body through urea, and because it is extremely soluble, it is a very efficient process. The average person excretes about 30 grams of urea a day, mostly through urine, but a small amount is also secreted in perspiration. Synthetic versions of the chemical compound can be created in liquid or solid form and is often an ingredient found in fertilizers, animal feed, and diuretics, just to name a few.

Physicians can use urea levels to detect diseases and disorders that affect the kidneys, such as acute kidney failure or End-Stage Renal Disease (ESRD). The Blood Urea Nitrogen (BUN) and the Urine Urea Nitrogen (UUN) tests, which measure urea nitrogen levels in the blood and urine, are often used to assess how well a patient's kidneys are functioning. Increased or decreased levels of the compound, however, do not always indicate kidney problems, but instead may reflect dehydration or increased protein intake [9]. Lectins are present in most foods such as peas, beans, cereal grains, etc. and thus form part of the normal human diet. Some foods contain Lectins which could be toxic to animals and humans. Lectins from castor bean are highly toxic and can kill if ingested even in small amount [10]. A few Lectins, such as the Lectin found in red kidney beans (the PHA Lectin), are known to damage the structure of the small intestine, or affect the pancreas and production of digestive enzymes when eaten by humans or animals [7].

The body's primary source of energy takes the form of glucose. This type of sugar comes from digesting carbohydrates into a chemical that can easily be converted to energy. A serious condition known as diabetes develops when glucose levels in the blood stream are not properly regulated. The digestive enzymes in the body using bile, break down the starch and sugar in foods into glucose. This functional form of energy then gets absorbed through the small intestine into the blood stream. There, a chemical known as insulin, excreted by the pancreas, meets the glucose. Together, they can enter cells in muscles and the brain, allowing glucose to power vital activities of the body like physical and mental functions.

Since glucose is such a vital form of energy, and interacts with both the digestive and endocrine systems, keeping it within a normal range is extremely important to health. The body has adapted to maintain this ideal level by storing extra glucose in the liver as glycogen, so it can be reabsorbed when the levels drop. The release of insulin can be slowed or sped up as well. However, at any step in the process, problems can arise in keeping the right amount of glucose circulating in the blood. Excessively high glucose levels, called hyper glycaemia, might be due to too much sugar or too little insulin. The opposite, extremely low glucose levels, can result from too little food or variable insulin excretion. A common disease related to irregular management of glucose is diabetes. Sometimes, diabetes can be controlled by strict dietary requirements, or a diabetic might need insulin injections [11].

Laboratory Rats have served as an important animal model for research in Physiology, Medicine and other fields. A Wistar Rat is an out bred strain of Albino or white Rat belonging to the species Rattus norvequicus. This is currently one of the most popular Rat strains for laboratory research [12].

Due to the numerous end uses applications of Lectins and the need to produce at cheaper rate indigenous reagents from local sources for routine diagnosis of many disorders including agglutination, identification studies and for therapeutic purposes inform the basis of embarking on this work.

The specific objectives of this research are to: 1. Isolate/Extract Achatina achatina snail Lectin (a local snail specie). 2. Purify the crude Achatina achatina snail Lectin 3. Determine the effects of the A. achatina Lectin on Leucopoiesis. 4. Assess the activities of the snail Lectin on Urea and Glucose levels. 5. To explore its commercial viability.

\section{Material and methods}

One Hundred and Twenty (120) samples of the local (Nigeria) Achatina achatina snail (Ejuna Ojii) were collected for analysis. The snails were put in sack bags enclosing their normal feeding diet and deposited with the Animal house of the University of Nigeria, Enugu-Campus (UNEC) for at least two weeks for acclimatization before analysis. The One Hundred and twenty (120) samples of the local snail-Achatinia achatina (Ejuna Ojii) analysed were sourced as follows: 
They were purchased at the Main Market Enugu and identified by a Zoologist at University of Nigeria, Nsukka, Enugu State, Nigeria. The snails were euthanized after acclimatization according to the method of Kristensen and Frandsen, 1984 [13] and their albumin glands extracted by dissection.

\subsection{Extraction of Achatina achatina Snail Lectin}

The albumin glands extracted following the dissection of the snails were weighed in a mettler balance and their gram weights noted. The weighed albumin glands were extracted according to the methods of Hammarstrom and kabat, 1969 [14], mixed with sodium azide preservative and were transferred by means of a Pasteur pipette into clean washed antisera bottles, corked and stored at $-20^{\circ} \mathrm{C}$. They were thawed before use at room temperature.

\subsection{Purification of Crude Achatina achatina Snail Lectin Extract}

The crude A. achatina extract was purified employing: Ammonium Sulphate Precipitation. Dialysis and Affinity Chromatography purification methods [15] and were carried out based on the following principles:

\subsubsection{Ammonium Sulphate Precipitation Method}

This is a simple and effective means of fractionating proteins. The principle is based on the fact that at high salt concentrations the natural tendency of proteins not to aggregate is overcome since the surface charges are neutralized. Charge neutralization means that proteins will tend to bind together, form large complexes and hence are easy to precipitate out by mild centrifugation.

\subsubsection{Dialysis Method}

Dialysis is a classic laboratory technique that relies on selective diffusion of molecules across a semi-permeable membrane to separate molecules based on size. The $20 \%$ Ammonium sulphate precipitate was thus dialyzed against water over night at $4^{\circ} \mathrm{C}$ under constant stirring using magnetic stirrer. At the end of the first day water dialysis period, it was re-dialyzed for a second day in $25 \mathrm{mM}$ Tris HCL buffer. After the two day dialysis periods, the content was transferred into sterile test tubes, corked and stored at $4^{\circ} \mathrm{Cready}$ for Affinity Chromatography purification stage.

\subsubsection{Affinity Chromatography Method}

The Affinity Chromatography column of choice used in this research for the complete purification of the Achatina achatina snail Lectin is Con A Sepharose 4B (HiTrap Con A 4B) which is a chromatography medium for separation and purification of glyco-proteins, polysaccharides and glyco-lipids. Con A Sepharose is an affinity medium with Concanavalin A (Con A) coupled to Sepharose 4B by the cyanogens bromide method [15].

\subsection{Haemagglutination of $\boldsymbol{A}$. achatina Snail Lectin}

Agglutination tests were carried out on the crude, partially purified and affinity chromatography purified extracts using scrupulously cleaned precipitation tubes in the standard tube technique and examined macroscopically and microscopically. The separately pooled and washed human ABO cells were washed four times in saline, and 5\% suspension of the cells were made and used for the agglutination tests both in the control test and actual tests as follows: Two methods were employed in doing this viz, tile and tube methods. In both methods, Presence of agglutination reactions were checked both macroscopically and microscopically.

\subsection{Exposure of the Albino Wistar Rats to Doses of the Affinity Purified Snail Lectin}

Thirty five (35) healthy male Albino Wistar Rats (Rattus norvegicus) weighing 101-212g and 2-3 months old were used for this study. They were obtained from the Animal house of the University of Nigeria, Nsukka and deposited with the Animal house of University of Nigeria, Enugu Campus (UNEC) and allowed for two (2) weeks of acclimatization before being subjected to experimental procedures. The Rats were maintained on standard Rat feeds (super starter, vital feeds) and portable water ad libitum and were handled in accordance with internationally accepted principles for Laboratory Animal use and care. The animals were randomly divided into five (5) groups (A-E) of seven (7) Rats per group and the body weight of each Rat determined using Mettler balance. Group E served as the control and were fed with the rat feeds and water only while groups A-D were the test groups injected Doses of the Affinity purified Lectin. Using Insulin syringe an intra-peritoneal injection was made with each animal receiving a calculated graded concentration of the purified Lectin based on their body weight $(0.04 \mathrm{ml}, 0.05 \mathrm{ml}, 0.06 \mathrm{ml})$ for the Rats weighing between 101 and $164 \mathrm{~g}$ respectively. The Lectin Doses were injected at Two (2) days intervals for One (1) week, at the end of which the animals were bled. 


\subsection{Blood Sample Collection and Analysis}

Two (2) ml of blood was collected from each of the Thirty-five (35) Albino Wistar Rats for Pre Lectin administration tests analysis. Twenty-four (24) hours after the last intra peritoneal Lectin Doses injections in the one (1) week period, Two (2) ml of blood sample was collected directly from the heart of each Rat via cardiac puncture after anaesthetizing the animals. One (1) $\mathrm{ml}$ of the collected blood specimen was delivered into appropriate concentration of EDTA anticoagulated tubes for determination of Total and Differential White blood cells count by means of Sysmex Corporation, 1999 automated equipment and the remaining one (1) $\mathrm{ml}$ of the collected blood specimen was transferred into tubes containing appropriate Lithium heparin anti-coagulant for Urea and Glucose estimations. Haemolysed plasma or sera were discarded. The collected normal plasma were stored at $4^{\circ} \mathrm{C}$ ready for use to assay the Urea and Glucose parameters and were performed using Urease-Berthelot and GOD-PAP Randox Monza automated analyzer methods respectively.

\subsection{White Blood Cells Count}

This was performed using Sysmex Corporation, 1999 automated equipment and is based on the principle that Sysmex KX2IN Haematology analyser performs blood cells count by the DC detection method. The blood specimens were collected into appropriate concentrations of EDTA anticoagulant containers and placed on the automated mixer for proper mixing of the blood samples and then analyzed.

\subsection{Determination of urea and glucose levels in Albino wistar rats}

The assay of Urea and Glucose estimations were performed by means of Urease-Berthelot and GOD-PAP Randox Monza automated analyzer methods respectively. The GOD-PAP Randox Monza automated analyzer method work based on the following principles: Pipette samples and reagents into sample cuvettes, mix sample and reagent (s), incubate reaction mixture at $37^{\circ} \mathrm{C}$ and then automatically read the absorbance of the reaction product after blanking with deionized water and automatically calculate the results by multiplying with test conversion factor. On the other hand, the UreaseBerthelot method work based on the principle that Urea in serum is hydrolyzed to ammonia in the presence of urease. The ammonia was then measured photometrically by Berthelot's reaction [16].

Normal Range For Blood Urea: $2.5-8.5 \mathrm{mmol} / \mathrm{L}$.

Normal Range FOR Blood Glucose: 3.6 - $5.6 \mathrm{mmol} / \mathrm{L}$ (Fasting glucose).

\section{Results}

The Mean, Standard Deviation (STD) and the P-value of all data obtained in this research are illustrated below in Tables 1 and 2. The tables depict the Analysis of Variance comparison of the Pre and Post A. achatina snail Lectin Doses exposure mean values of the assessed Leucocytes parameters and the Glucose and Urea levels in the Albino Wistar Rats respectively.

Figures 1 and 2 represent the Bar Chart variations in the Pre and Post Lectin Doses injections mean values of the assessed Leucocytes parameters in the animals. Also, Figure 3 is the Bar Chart showing variations in the Pre and Post Lectin Doses injections mean values of Urea and Glucose levels in the Albino Wistar Rats. Figures 4 and 5 show the Haemagglutination pattern of the Lectin in saline control and with Blood group A Cells respectively. The Tables and Figures obtained in this research are as shown below:

Table 1 Analysis of variance comparison of the Pre and Post Achatina achatina Snail Lectin Doses Injections Mean Values of the Assessed Leucocytes Parameters in the Albino Wistar Rats

\begin{tabular}{|l|c|c|c|c|l|}
\hline Parameters & Groups & $\begin{array}{c}\text { Mean } \\
\text { Difference } \\
\text { Values }\end{array}$ & F-Value & $\begin{array}{c}\text { P- } \\
\text { Value }\end{array}$ & Remark \\
\hline Total White Blood Cell & A & 1.4920 & & & \\
(TWBC) Count (X109/L) & B & 1.2720 & & 0.407 & Not \\
& C & 2.3480 & 1.042 & & Significant \\
& D & 1.3650 & & \\
& E & 0.8221 & & \\
\hline
\end{tabular}




\begin{tabular}{|c|c|c|c|c|c|}
\hline Lymphocytes (LYM) (\%) & $\begin{array}{l}\text { A } \\
\text { B } \\
\text { C } \\
\text { D } \\
\text { E }\end{array}$ & $\begin{array}{c}1.8060 \\
1.9300 \\
3.2260 \\
1.3583 \\
-3014\end{array}$ & 1.764 & 0.171 & $\begin{array}{l}\text { Not } \\
\text { significant }\end{array}$ \\
\hline Neutrophils (NEU) (\%) & $\begin{array}{l}\text { A } \\
\text { B } \\
\text { C } \\
\text { D } \\
\text { E }\end{array}$ & $\begin{array}{c}3260 \\
-2560 \\
7480 \\
1.0150 \\
0.0343\end{array}$ & 0.754 & 0.567 & $\begin{array}{l}\text { Not } \\
\text { significant }\end{array}$ \\
\hline Monocytes (MON) (\%) & $\begin{array}{l}\text { A } \\
\text { B } \\
\text { C } \\
\text { D } \\
\text { E }\end{array}$ & $\begin{array}{l}-7940 \\
-2300 \\
-8940 \\
-4683 \\
.4800\end{array}$ & 2.754 & 0.094 & $\begin{array}{l}\text { Not } \\
\text { significant }\end{array}$ \\
\hline Eosinophils (EOS) (\%) & $\begin{array}{l}\text { A } \\
\text { B } \\
\text { C } \\
\text { D } \\
\text { E }\end{array}$ & $\begin{array}{c}0.1680 \\
-0.1200 \\
-0.5880 \\
-0.1640 \\
-0.5771\end{array}$ & 3.253 & 0.031 & $\begin{array}{l}\text { Significant } \\
\text { Not sig. } \\
\text { Not sig. } \\
\text { Not } \\
\text { significant }\end{array}$ \\
\hline Basophils (BAS) (\%) & $\begin{array}{l}\text { A } \\
\text { B } \\
\text { C } \\
\text { D } \\
\text { E }\end{array}$ & $\begin{array}{c}-0.140 \\
-0.520 \\
-0.1440 \\
-0.2467 \\
-0.2086\end{array}$ & 1.306 & 0.297 & $\begin{array}{l}\text { Not } \\
\text { significant }\end{array}$ \\
\hline
\end{tabular}

Table 2 The analysis of variance comparison of the Pre and Post Achatina achatina Snail Lectin Administration Mean Values of Glucose and Urea Tests Levels in the Albino Wistar Rats.

\begin{tabular}{|l|c|c|c|l|l|}
\hline Parameters & Groups & $\begin{array}{c}\text { Mean } \\
\text { Difference } \\
\text { Values }\end{array}$ & $\begin{array}{c}\text { F- } \\
\text { Value }\end{array}$ & $\begin{array}{c}\text { P- } \\
\text { Value }\end{array}$ & Remark \\
\hline & A & 5.9840 & & & \\
Glucose (GLU) (mg/dl) & B & 5.4620 & & 0.425 & Not \\
& C & 5,7920 & 1.005 & & significant \\
& D & -52.5650 & & & \\
\hline & E & 3.1443 & & & \\
Urea (mmol/L) & A & 6.6840 & & & Not \\
& B & $-2,2820$ & & 0.125 & significant \\
& C & -1.4280 & 2.019 & & \\
\hline & D & -2.2833 & & & \\
& E & -2.6441 & & & \\
\hline
\end{tabular}



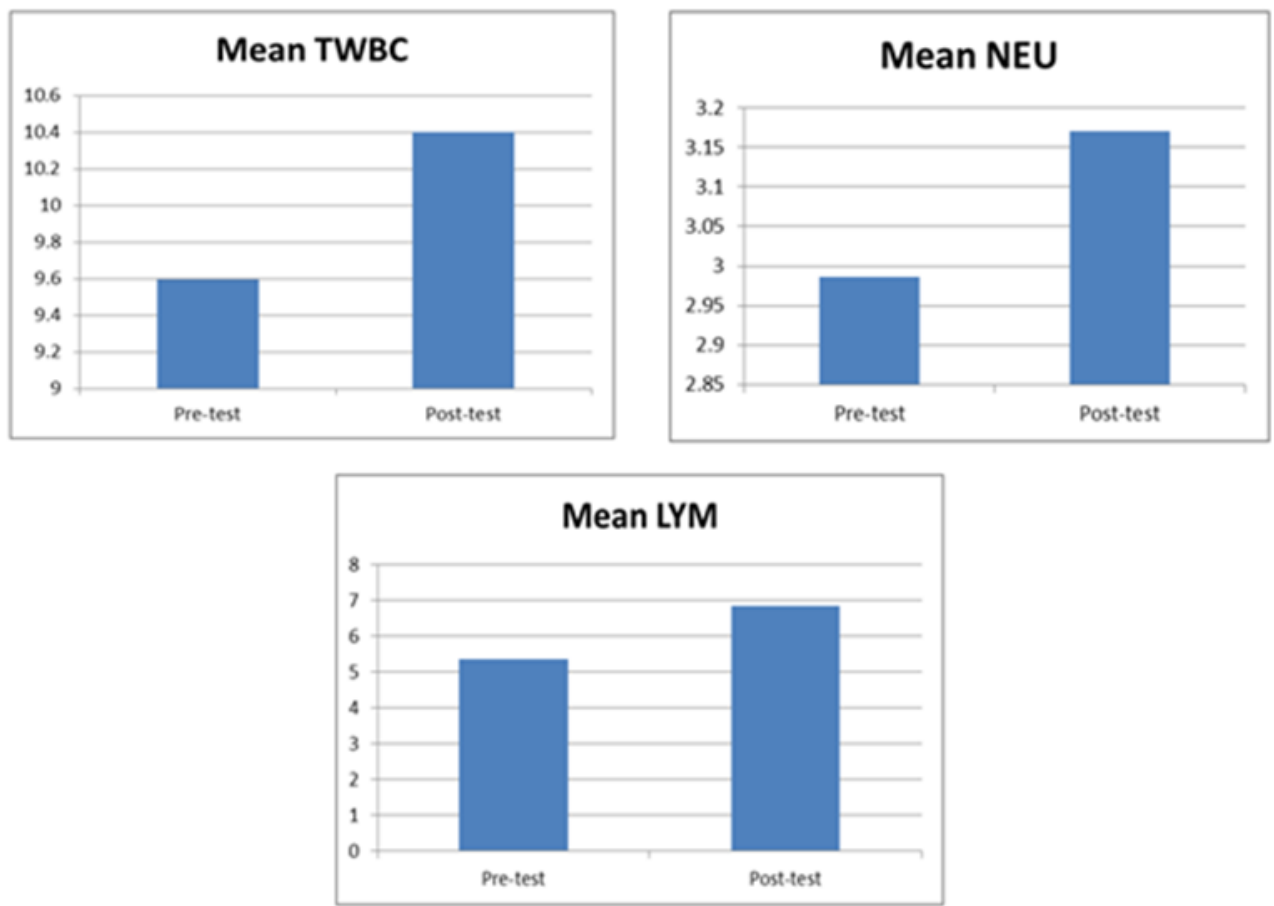

KEY: TWBC $=$ Total White Blood Cells Count; NEU = Neutrophils; LYM = Lymphocytes

Figure 1 The Bar Chart Depicting the Variations in the Pre and Post Snail Lectin Doses Injections Mean Values of Total White Blood Cells Counts, Absolute Neutrophils and Lymphocytes Levels in the Albino Wistar Rats
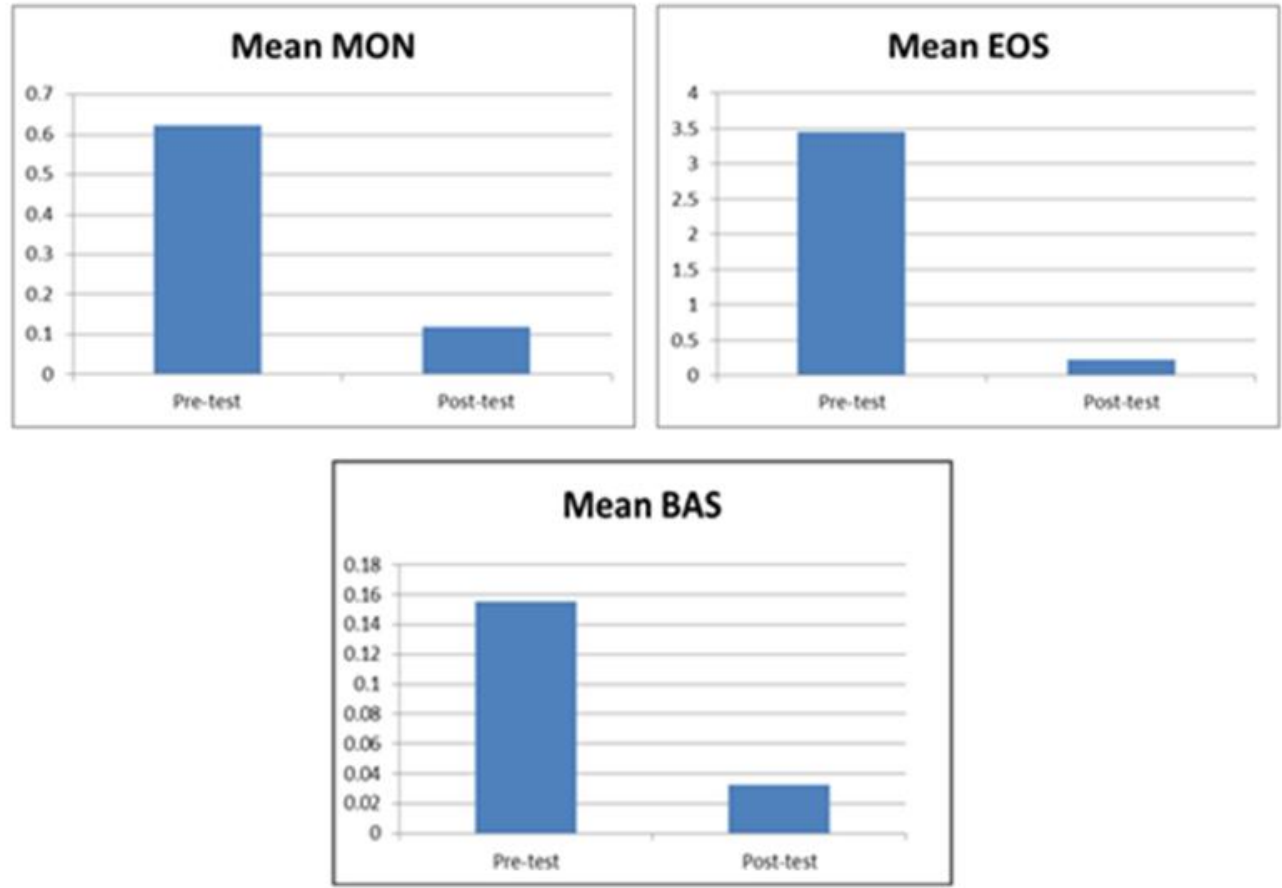

KEY: MON = Monocytes; EOS = Eosinophils; BAS $=$ Basophils

Figure 2 The Bar Chart of the Pre and Post Snail Lectin Doses Injections Variations of the Mean Absolute Values of Monocytes, Eosinophils and Basophils in the Albino Wistar Rats 

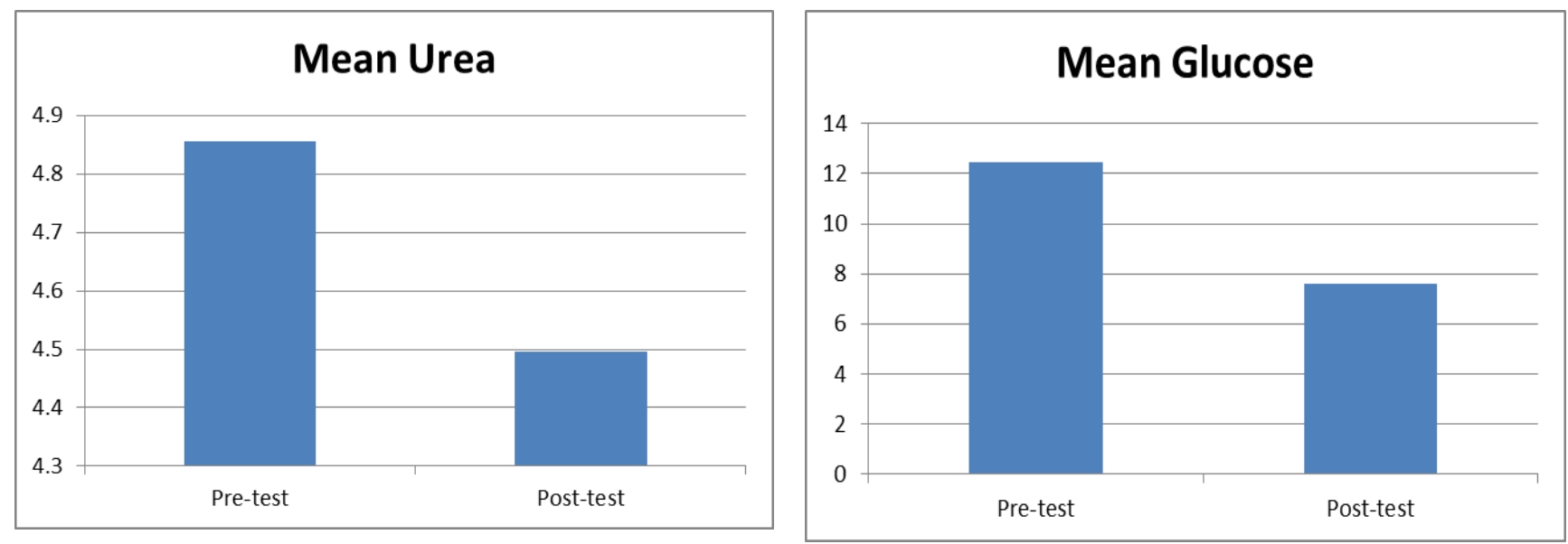

Figure 3 The Bar Chart Showing Variations in the Pre and Post Snail Lectin Doses Injections Mean Values of Urea and Glucose in the Albino Wistar Rats

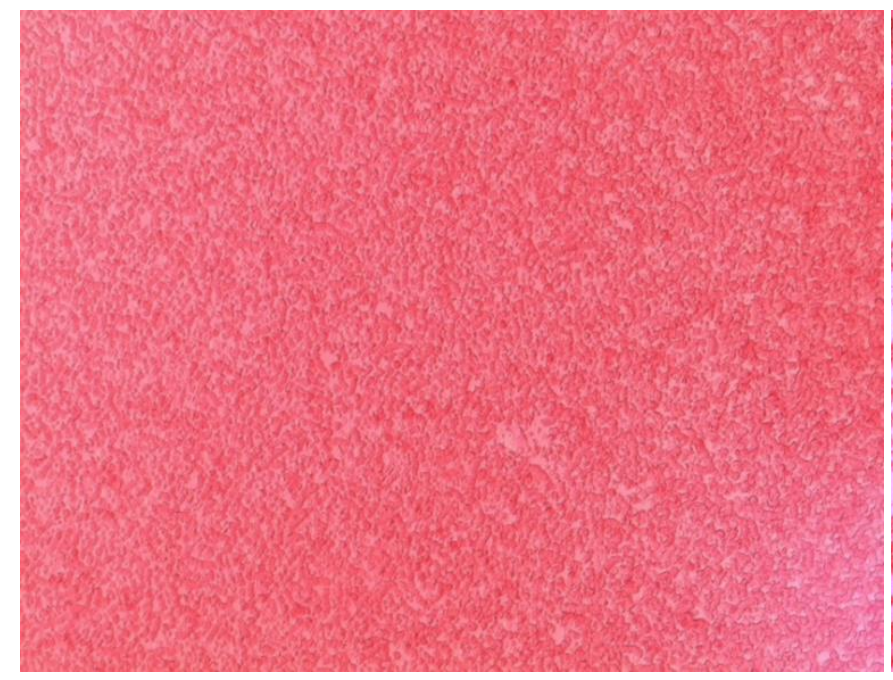

Figure $410 \mathrm{x}$ photomicrograph of phosphate buffer saline haemagglutination negative control

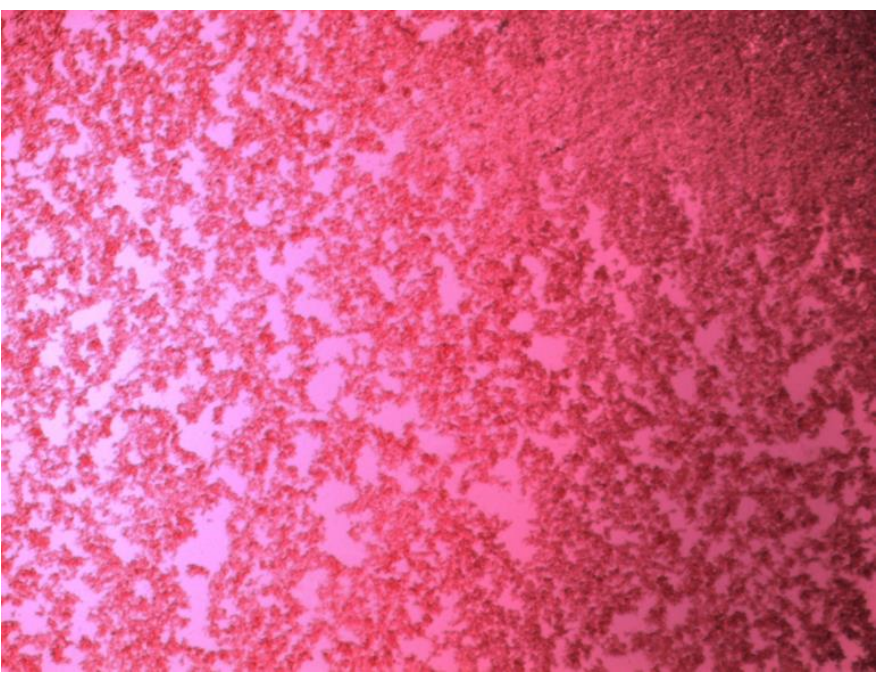

Figure 510 x photomicrograph haemagglutination pattern of the Achatina achatinalectin with human blood group a cells

\section{Discussion}

The mechanism of haemagglutination by Lectins relies upon the bridging of red cells with the extract molecules coupled with the specific lattices of the erythrocytes. Since several thousand sites for each antigen are present on each single erythrocyte, there is ample opportunity for the lattice formation needed to create easily visible clumps of erythrocytes. One other factor that influences the cross reactions between Lectins and human blood groups, border on their combination with several sugar components on the red cell membrane. Thus, the haemagglutination activity assay obtained in this research depicts the A. achatina Snail Lectin extract as a glyco-protein with Lectinic properties. Here, the Crude, Ammonium sulphate precipitate, Dialyzed and Affinity Chromatography purified A. achatina Snail Lectin extracts, all cross reacted in different agglutinating strengths with human ABO blood cells and at dilution of 256, reacted only with group A type and thus possess Lectinic properties. This is in support of the works of Hammerstrom and Kabat, 1969 [14]; Tsut sui et al., 2003 [17]; Ukaejiofo and Odiegwu, 2010 [18]; Ito et al., 2011 [19]. However, all the investigations carried out in this research were performed using the Affinity purified Lectin because it gave improved reactivity and is free from other proteins or contaminants except the A. achatina glyco-protein of interest. In this way, results derived herein could rightly be attributed to the snail Lectin. The Phosphate buffered saline negative control and 
the Haemagglutination pattern of the A. achatina Snail lectin with human blood group A cells respectively are shown in Figures 4 and 5.

The 35 Albino Wistar Rats used for the experimental study were grouped into 5 of 7 Rats per group. The groups (A- E) mean difference, control versus the test groups (A-D) mean difference, F and P-values of the assessed Leucocytes parameters in the Albino Wistar Rats exposed to the doses of the Affinity purified A. achatina Lectin are shown in Table 1, while Glucose and Urea levels are illustrated in Table 2. Bar charts statistics were used to summarize the results of the Pre and Post Achatina achatina Lectin Doses injections values of the Affinity purified A. achatina Lectin in the Albino Wistar Rats. The Bar charts statistics show that there was Post Lectin administration mean increase in Total White blood cells (TWBC) count, absolute numbers of Neutrophils (NEU) and Lymphocytes (LYM) and these indicate that the Lectin could stimulate active Leucopoiesis. On the other hand, there was Post Lectin administration Bar Chart mean decrease in absolute values of Monocytes (MON), Basophils (BAS), Eosinophils (EOS), Urea and Glucose (GLU) levels. These deductions show the Lectin as nontoxic, not a pathogen, non-carcinogenic, capable of lowering or maintaining blood glucose to normal levels and point to its nutritive value as food stuff, and that it could be transformed into vials for treatment purposes. However, the differences in the Post and Pre administration mean values of these assessed parameters were further subjected to one way analysis of variance (ANOVA) test statistics with a view to determining whether the Bar Chart mean increases or decreases in these assessed parameters were statistically significant.

The One way Analysis of Variance (ANOVA) comparison of the Pre and Post A. achatina Snail Lectin Doses injections mean values of the assessed Leucocytes parameters viz, TWBC, LYM, NEU, MON and BAS were found not to be statistically significant ( $p>0.05$ ) except EOS where the group A values only was statistically significant $(p=0.006)$. Similarly, the Bar Chart statistics Post Lectin administration decrease in Glucose and Urea levels were found to be statistically insignificant in all the test groups $(\mathrm{P}>0.05)$ by the ANOVA test statistics. This is not in support of the works of Damme et al., 1998 which say that different Lectins are associated with different diseases. For instance, it has been shown that diary based Lectins are associated with juvenile on set type 1 diabetes [20]. But this particular Lectin from the results deduced from this research is not associated with causing elevation or too much decrease of blood glucose levels (diabetes mellitus or diabetes insipidus respectively), is nontoxic (as the Urea levels in the test groups are normal), not a pathogen, non-carcinogenic (as the Leucocytes values are within normal ranges and active Leucopoiesis were stimulated in the Rats exposed to Doses of the Lectin) and therefore points to its nutritive value as food stuff, hence calls for support to snail eating education and possible commercial production and transformation of the Lectin into vials for treatment purposes. This research has therefore succeeded in the Purification and determination of the effects of the Isolated Nigeria Achatina achatina Snail Lectin on Leucocytes, Urea and Glucose levels.

\section{Conclusion}

The research findings show the Achatina achatina Snail Lectin as nontoxic, non-carcinogenic, not a pathogen, point to its nutritive value as food stuff, and hence calls for support for snail eating education and possible commercial production and transformation into vials for treatment purposes. The snail Lectin demonstrated Lectinic properties as it cross reacted with human ABO Erythrocytes. The reaction with human ABO cells was at different agglutinating strengths and at titre of 256 it reacted specifically with human blood group A type. Active Leucopoiesis was seen in the experimental animals exposed to the doses of the Lectin. Also, the MON, EOS, BAS, Urea and Glucose levels of the animals administered with the Lectin were not adversely altered and these deductions, classify the A. achatina Snail extract as a Lectin with useful Leucopoietic, non-Toxic and Nutritive properties.

\section{Recommendations}

In view of the findings deduced from this research, it is hereby recommended that further research activities on this Lectin be intensified with a view to commercially producing local or indigenous Lectin products that could serve as an adjunct or potent agents for treatments, routine diagnosis of many health disorders including agglutination and identification studies etc. The future research should be focused on the activities of the Lectin on other areas of Biomedical Sciences and Molecular biology.

\section{Compliance with ethical standards}

This research is in full compliance with ethical standards and moreover, human subjects were not used while conducting this research. 


\section{Acknowledgments}

We hereby acknowledge the Tertiary Education Trust Fund (TETFund) of Nigeria for the Research grant Awarded to the corresponding Author that made possible the comprehensive analysis of this snail Lectin to be conducted at the Department of Advanced Diagnostics and Biosensors, Cranfield University, Cranfield, Bedfordshire, England, United Kingdom. This is because, this research has many limitations including locally unavailable, scarce or very expensive molecular equipment, chemicals, reagents, expertise etc., but through the TET Fund Research grant intervention, the objective of this research was achieved. Thus, we appreciate the corresponding author Re: Dr. C.N.C. Odiegwu for the judicious use of the TET Fund grant including payment of the Bench Fees to Cranfield University, which enabled the provision of the much needed expertise, supervision, technology, equipment etc. by the Cranfield University, Cranfield, Bedfordshire, England, and United Kingdom.

\section{Disclosure of conflict of interest}

There is no conflict of interest amongst the authors as all the authors contributed in one way or the other in conducting the research and in writing the manuscript which was eventually articulated and submitted for publication by the corresponding author.

\section{Statement of ethical approval}

The present study is an analysis of data from Albino Wistar Rats housed in the animal house of University of Nigeria, Enugu Campus. As per International standard or University standard, this research work is in full compliance with the International ethical standards principles of laboratory animal use and care that is preserved by the University.

\section{References}

[1] Cheesbrough M. District Laboratory Practice in Tropical Countries. Part 2. Blackwell Scientific Publications, Oxford. 2006; $317-319$.

[2] Ochei J., Kolhatkar A. Subgroup of the ABO blood group system. Medical Laboratory Science Theory and Practice. 2nd edition. Tata McGraw Hill Publishing Company limited, New Delhi. 2005; 352-356.

[3] Dutta A.B. History, inheritance, Antigens and Antibodies of ABO blood group system. Blood banking and transfusion. 1st edition. CBS publishers, New Delhi, India. 2006; 67-74.

[4] Pohleven J., Strukelj B., Kos J. Affinity Chromatography of Lectins. 2012. http ://www.intechopen.com.

[5] Krispin S. C. The lectin report. 1 ${ }^{\text {st }}$ edition. Churchill Livingstone, Edinburgh, U.K. 2008; 35 - 40

[6] Dadamo P. Link Informatics for Lectins. Journal of biological sciences. 2006; 8 (1):17 - 24.

[7] Pusztai A. Plant Lectins. Part 1. Cambridge University Press, England. 1991; 108.

[8] Davin J.C., Senterre J., Mahieu P.R. The high lectin-binding capacity of human secretory IgA protects nonspecifically mucosae against environemtnal antigens. Bio Neonate. 1991; 59(3): 121-125.

[9] Bostwick G., Oppenheimer J. Blood Urea. 2011. http:/malecare.org/ second-opinion on-biopsy-slides.

[10] Wikipedia. Lectin. 2008. http://en.wikipedia.org/wiki/lectin.

[11] Mithra S., Wynn L.S. What is glucose? 2011. http://www.wisegeek.com/ what-is-glucose.htm.docs.goggle.com.

[12] Krinke A.B., George J. History Strains and Models. The Laboratory Rat (hand book of experimental animals). 2nd edition. Tracie Academic press, UK. 2000;3 - 16

[13] Kristensen T.K., Frandsen F. Methodology for Snail Dissection and Preparation. WHO - Danish Bilharziasis Laboratory Journal. 1984; (II): 5-8.

[14] Hammerstrom S., Kabat E.A. Purification and Characterization of a Blood group A. re-active haemagglutinin from the snail Helix pomatia and a study of its combining site. Biochemistry. 1969; 8: 2696 - 2705.

[15] GE Healthcare Bio-sciences. HiTrap Con A 4B Affinity Columns Instructions. 2014. www.gelifesciences.com/protein-purification.

[16] Randox Laboratories. Blood Glucose and Urea Estimations by Gluc-Pap and Urease-Berthelot Methods respectively. Randox Laboratories Ltd. 55 Diamond Road, County Antrim, BT29 4QY, United Kingdom. 2014. 
[17] Tsutsui S., Tasumi S., Suetake H., Suzuki Y. Lectins homologous in those of monocotyledonous plants in the skin mucus and intestine of pufferfish, Fugu rubripes. Journal of Biological Chemistry. 2003; 278: 20882-20889.

[18] Ukaejiofo E.O., Odiegwu C.N.C. Comparative Studies of Agglutination Properties of Lectins of Some Tropical Snails with Lectins from Arachis hypogeae (A Legume). International Journal of Biological Science. 2010; 2(3): 103 -107.

[19] Ito S., Shimizu M., Nagatsuka M., Kitajima S., Honda M., Tsuchiya T., Kanzawa N. High Molecular Weight Lectin Isolated from the Mucus of the Giant African Snail Achatina fulica. Biosci. Biotechnol. Biochem. 2011; $75(1)$ : 20 25 .

[20] Damme E.J., Peumans W.J., Barre A., Rouge M.V. Plant Lectins: A composite of several distinct families of structurally and evolutionally related proteins with diverse biological roles, crystal reviews in plant sciences. 2nd edition. Churchill Livingstone, Edinburgh, UK. 1998; 575-692.

\section{Author's short biography}

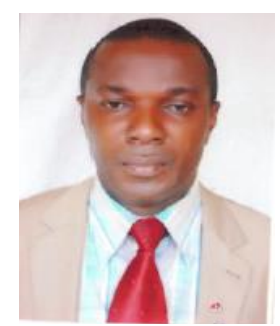

Dr. Odiegwu Chukwujekwu Nwabueze C. was born in Enugu, Enugu State, Nigeria and hails from Abacha in Idemili North Local Government Area of Anambra State, Nigeria. He had Academic tutelage of over three decades, studying under numerous Teachers, Lecturers and Professors at Ogbete River Primary School, Enugu; Sacred Heart Seminary, Nsude-Enugu; St. John Cross Seminary, Nsukka; National Grammar School, Nike-Enugu; University of Nigeria, Nsukka; University of Nigeria, Enugu Campus cum University of Nigeria Teaching Hospital, Enugu all in Enugu State, Nigeria; Cranfield University, Cranfield, and Staffordshire University, Stoke both in England, United Kingdom (UK). Following the completion of his National Youth Service Corps (N.Y.S.C.) with the Medical Centre (Sick Bay) of the Nigeria Naval Ship Urhiapele (Naval Base), Ogorode, Sapele, Delta State, Nigeria in 1996, he delved into Diagnostic Medicine Practice. Consequently, he became the Director of Jenic Associates, a conglomerate of Clinical Diagnostic Laboratories, Research, Pharmacy and Clinical Services.

Dr. C.N.C. Odiegwu's passion for Academics prompted him to enrol for Postgraduate studies at University of Nigeria, Enugu Campus culminating in his obtaining Master of Science (M.Sc.) Degree in Haematology and Blood Transfusion Science in May, 2006. In August, 2008, he embarked on Doctor of Philosophy (Ph.D) Degree in Haematology and Blood Transfusion Science of the University of Nigeria, Nsukka. In September, 2013 his Ph.D Programme was near completion and needed Bench Work Research to complete, but owing to lack of certain Equipment, Facilities, Materials, Expertise locally, he had to undergo Overseas Ph.D Bench Work Research at Department of Advanced Diagnostics \& Biosensors, Cranfield University, Cranfield, Bedfordshire, England, UK following the Award of Research Grant to him by Tertiary Education Trust Fund (TETFund) of Nigeria. To the Glory of God, despite his chequered experiences, he conducted the Overseas Bench Work Research and successfully defended and obtained the Ph.D Degree in July, 2014. Consequent upon the advised need to study Molecular Biology since it is central to success in his areas of Research, he enrolled with self-funds for Master of Science (M.Sc.) Degree in Molecular Biology with Staffordshire University, Stoke, England, UK and commenced studies in September, 2019. Owing to CoVID-19 Pandemic he couldn't finish the Programme as scheduled but however, is set to complete and successfully obtain the Staffordshire University, England, UK M.Sc. Degree in Molecular Biology in November, 2022.

In recognition of his giant strides in Academics, Nnamdi Azikiwe University (Unizik), Awka, Anambra State, Nigeria had to appoint him Haematology \& Blood Transfusion Science Lecturer II to Department of Medical Laboratory Science, College of Health Sciences, Unizik, Nnewi Campus on $14^{\text {th }}$ May, 2008. He was promoted to Lecturer I by the University on $1^{\text {st }}$ October, 2011, to Senior Lecturer on $1^{\text {st }}$ October, 2015 and Associate Professor on $1^{\text {st }}$ October, 2019. His meritorious Academic conducts and Teachings prompted the Enugu State University of Science \& Technology (ESUT), Agbani, Enugu State, Nigeria to appoint him Adjunct Senior Lecturer in Haematology \& Blood Transfusion Science to Department of Medical Laboratory Science, College of Medicine, Park Lane, Enugu Campus on $2^{\text {nd }}$ June, 2017. Similarly, Chukwuemeka Odumegwu Ojukwu University, Igbariam, Anambra State, Nigeria was pleased to appoint him Sabbatical Senior Lecturer in Haematology \& Blood Transfusion Science and Charter Head of Department (HOD) for the establishment of New Department of Medical Laboratory Science in the University in May, 2021.

Dr. Odiegwu C.N.C. is a Member of many Academic, Professional, Pious and Humanitarian bodies including: Member Academic Staff Union of Universities (ASUU); Member International Research and Development Institute (IRDI); Member Association of Medical laboratory Scientists of Nigeria (AMLSN) and is the Charter Chairman of the Unizik Chapter of the Association; A devout Catholic and Member League of Sacred Heart of Jesus; A Rotarian since October, 2000 and was Installed the 18 ${ }^{\text {th }}$ President of the Rotary Club of Enugu-South in 2002-2003 Rotary year. His devotion 
to the goals of Rotary prompted the then District Governor to appoint him District Governor's Special Representative (DGSR) for the formation of Rotary Club of Awka-Nnamdi Azikiwe University in 2009 and he was Installed the Charter President of the Club 2009-2011 Rotary year; Member of Igwe Cabinet and Nze na Ozo Society of Abacha and was Bestowed with Chieftaincy Title of Ezeamama of Abacha by Igwe of Abacha since August, 2018.

As a prolific Academic, Dr. Odiegwu has many Research Publications in both Local and InternationalJournals to his credit. Currently, his Research interest is focused on Purification, Characterisation and Applications of Tropical Lectins, including on Molecular Haemato-Oncology. He is happily married to his lovely wife - Ugochinyerem (a Statistician) and they are blessed with Chibudom, Tobeolise and Adaolise. To God is the Glory! 


\section{Leucocytes, urea and glucose levels in Albino Wistar rats exposed to doses of isolated Achatina achatina snail lectin}

Odiegwu, Chukwujekwu Nwabueze C.

Magna Scientia Publication

Odiegwu CN, Chianella I, Odiegwu UO, et al., (2021) Leucocytes, urea and glucose levels in Albino Wistar rats exposed to doses of isolated Achatina achatina snail lectin. World Journal of Biology Pharmacy and Health Sciences, Volume 6, Issue 3, pp. 001-012

https://doi.org/10.30574/wjbphs.2021.6.3.0052

Downloaded from Cranfield Library Services E-Repository 